\title{
The crossing and production of lamb : Comparison and selection of male breeds
}

\author{
J. C. FLAMANT $(*)$ and G. PERRET $(* *)$ \\ (*) Station d'Amélioration génétique des animanx. Centre de Recherches de Toulouse, \\ I.N.R.A., B.P. I2, 31320 Castanet Tolosan. \\ (**) I.T.O.V.I.C., 34, bd de la Gave, 31500 Toulouse.
}

First generation crossbreeding experiments for lamb production were realized during 1976 through the collaboration of the I.N.R.A., the I.T.O.V.I.C. and the Midatest. They clearly confirm differences in the growth rate and conformation of sire breeds, criteria which can be observed on live animals. But carcass measurements indicate large differences in tissue composition (especially total fat) and in the distribution of adipose tissue. Texel sires give leaner carcasses at same weight, and Berrichon cross lambs are the fattest with the largest dorsal fat deposits. Lacaune have the greatest proportion of bone, but adipose tissue is mostly internal with little dorsal fat.

Several questions remain to be studied

- Can genotypes always be classed in the same way, whatever the breeding system used and the type of lamb desired?

- What is the possibility of selecting for restricted carcass fatness; is this selection in opposition with conformation and maternal abilities?

For the breeders, we advocate the creation of a single progeny test station for several breeds, where each breed can be given the best orientation for its selection.

\section{Adipose tissue development in meat lambs : effect of type of fat incorporated into the milk replacer}

\author{
B. AUROUSSEAU and M. THERIEZ
}

Laboratoire d'Étude du Métabolisme inergétique. Station de Recherches sur l'Elevage des Riuminants. Centre de Recherches de Clermont-Ferrand, I.N.R.A., Theix, 63IIO Beaumont (France).

A first trial involving 12 Charmois lambs demonstrated the significant effect of tricaprylin ingestion before weaning on adipose tissue composition at weaning (35 days) and at slaughter (I 20 days, $28 \mathrm{~kg}$ ). Saturated fatty acid content of the back fat thus decreased at weaning from 38.9 to $33.3 \%$, and the content of unsaturated fatty acid increased from 38.3 to $44.2 \%$. At slaughter the saturated fatty acid content of the back fat at the same site decreased from 37.8 to $31.6 \%$, while the unsaturated fatty acid content increased from 50.5 to $52.9 \%$; odd and branched-chain fatty acid content increased from 11.6 to $16.0 \%$. Again, at slaughter saturated fatty acid content of the inner back-fat decreased from 56.2 to $50.2 \%$ and unsaturated fatty acid content increased from 38.3 to $44.2 \%$.

In a sccond trial involving 59 Limousin or Limousin $\times$ Romanov lambs, slaughtered at weaning ( 28 lambs) or at $35 \mathrm{~kg}$ of weight ( $3 \mathrm{I}$ lambs), direct and long-term effect of tricaprylin 
on adipose tissue development were studied. At weaning, tricaprylin ingestion decreased fat content of the carcasses from 20.5 to $17.2 \%$. All of the adipose tissues were individually affected to about the same degree. When lambs weaned at 35 days were slaughtered, tricaprylin led to an indirect effect as opposed to its effect at weaning; fat content of the carcasses increased (non-significantly) from 24.8 to $26.2 \%$. With lambs weaned when 45 days old, the opposite effect was obtained: fat content of the carcasses decreased significantly from 29.6 to $26.6 \%$. This difference might be explained by the significant increase in the proportion of adipose tissues in the carcasses of lambs fed the conventional milk replacer (from 24.8 to $29.6 \%$, according to age at weaning) mostly resulting from an increase of intermuscular fat in those lambs.

In both cases (weaning at 35 or at 45 days), the type of milk given before weaning does not change inner fat. Tentative multivariate analysis shows variations of the long-term effect of tricaprylin or conventional fat with genetic type, type of breeding (single, double or triple) rate of growth before or after weaning. It is concluded that it is not possible now to further improve the carcass quality of lambs by the type of milk replacer, but that analysis of the unfavorable effects observed opens the way to new possibilities.

\title{
Use of lactose and urea in the diet of the fattening lamb at weaning
}

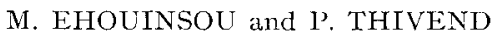 \\ Station de Recherches sur l'Elevage des Ruminants, \\ Centre de Recherches de Clermont-Ferrand, I.N.R.A., Theix, 63 IIo Beaumont
}

This report studies the utilisation of lactose and urea in feed for fattening lambs. Four

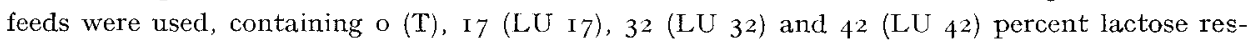
pectively in the form of ultrafiltrated whey. These fecds contained the same quantities of soyabean meal, lucerne and straw and $\mathrm{r} .5, \mathrm{~T}, 2.4$ and $2.7 \%$ urea (Table I). They were given to $4^{2}$ weaned lambs weighing about $20 \mathrm{~kg}$ at the beginning of the experiment. The animals were fed so that they received the same amounts of gross energy and nitrogen. Animal growth rate and the feed efficiency of different diets were measured. Animals were usually slaughtered at $35 \mathrm{~kg}$; the carcass composition (muscle, fat, bone) was determined and, using the difference with the animal carcass at the beginning of the experiment, gains in carcass weight and in different tissues were calculated.

The presence of lactose and urea in the feed slightly improved animal liveweight gain and feed efficiency of the ration (Table 2). Dressing percentage was greatly increased (from 3 to $5 \%$ ) (Table 3 ) and carcass composition highly modified (Table 4). Lambs receiving lactose formed more muscle, but with the same quantities of fat as those of the control group. A change in rumen fermentation by increasing butyric and propionic acid production, and the very good utilisation of non-protein nitrogen by rumen microflora might account for the better use for growth of the end-products resulting from digestion of lactose containing diets. 